\title{
Secondary Production in waters Influenced by Upwelling off the Coast of Somalia
}

\author{
Sharon Louise Smith \\ Oceanographic and Atmospheric Sciences Division \\ Department of Applied Science \\ Brookhaven National luaboratory \\ Upton, NY 11973
}

\begin{abstract}
DISCLAIMER
This report was prepared as an account of work sponsored by an agency of the United States Government. Neither the United States (jovernment nor any agency thereof, nor any of their employees, makes any warranty, express or implied, or assumes any legal liability or resporisibility for the accuracy, completeness, or usefulness of any information, apparatus, product, or process disolosed, or represents that its use would not infringe privately owned rights. Refor. ence herein to any specific commercial proluct, process, ar service by trade name, trademark, manufacturer, or otherwise does not necessarily constitute or imply its endorsement recom. Inendation, or favoring by the United States (iovernment or any agency thereof. The views and opinions of authors expressed herein do not necessarily state or reflect those of the United States Government or any ugency thereot.
\end{abstract}

This research was performed under the auspices of the United states Department of Energy under Contract No. DE-ACO2-76CH00016.

By acceptance of this article, the publisher and/or recipient acknowledges the U.S. Government's right to retain a nonexclusive, royalty-free license in and to any copyright covering this paper. 


\begin{abstract}
During the southwest monsoon of 1979, plankton samples were collected between the equator and $12 \%$. Surface samples collected while the research vessel was surveying this area have been analyzed for the abundance of copepod nauplii, primarily the young of the copepod calanoides carinatus. These samples revealed a sharp $r$ ise in the abundance of nauplii in regions where sea-surface temperatures were less than $19^{\circ} \mathrm{C}$. The developmental state of the gonads of femalle $C$. carinatus also showed that reproduction was likely to be most intense nearshore in cold, recently upwelled water. Lipid content of females was inversely related to gonad develiopment, suggesting that lipids sequestered at some earlier point in the life cycle were being used to synthesize eggs. secondary production is therefore highest in the nearshore areas having cool sea-surface temperatures. Growth of phytoplankton and growth of $C$. carinatus seem to be closely coupled; daily ingestion rates estimated in nearshore areas where potential secondary production was high were equal to or greater than measured rates of primary production.
\end{abstract}


Introduction

The copepod calanoldes carinatus is a common and prominent member of the plankton of upwelling areas around the African continent from northwestern Africa (Boucher et al., 1975; Schnack, 198.2) to Ivory Coast (Binet and suisse de Sainte claire, 1975) to Ghana (Mensah, 1975) to southwest Africa (Borchers and Hutchings, 1986) to the Somali coast (Smith, 1982). Its abundance and relatively large size for tropical, epipelagic plankton make it an appealing subject for study. Off Somalia, it has been shown to dominate the biomass of zooplankton during the upweling season in two different years, 1964 and 1979 (5mith, 1984). Its secondary production off Somalia can now be estimated, using old samples and techniques developed since 1979. The very high concentrations of mesopelagic fish in the region (Banse, 1984) cause one to try to estimate the secondary productivity that might support the mesopelagic fish. Widespread suboxic conditions in the Arabian sea basin below $200 \mathrm{~m}$ (Wyrtki, 1973; Swallow, 1984) suggest that coupling between primary and secondary production may not be close. Thus, there is an apparent contradiction. Large biomass of mesopelagic fish suggests a coupled and efficient food chain, while low oxygen conditions suggest a lack of coupling between primary and secondary production. Secondary productivity of a dominant herbivore such as calanoides carinatus is a key variable that should indicate how the epipelagic food chain of this region is structured. 
Materials and Methods

Zooplankton were collected from R.V. Columbus Iselin in oblique hauls of Bongo frames fitted with 223 and $333 \mu \mathrm{m}$ mesh nets and T.S.K. and General oceanics flowmeters. A mechanical timedepth recorder (Benthos) was mounted one meter above the net mouth. The collection from the $223 \mu \mathrm{m}$ mesh net was preserved in 5 neutral formalin-seawater solution. Underway samples of zooplankton were collected on $102 \mu \mathrm{m}$ mesh for five minutes each hali-hour during steaming from the output of a through-hull fitting 2 below the waterline. Samples were preserved in $5 \%$ neutral formalin seawater solution. Temperature, salinity, chlorophyll $\underline{a}$, and rate of flow were observed at the same time. A detailed account of the methods and data is in smith and Lane (1981).

Dry weights of various copepodid stages were determined by picking a number of individuals of a given stage from a sample, rinsing the specimens several times in distilled water and transferring them to a preweighed dish for drying at $50^{\circ} \mathrm{C}$. Dishes were reweighed using a cahn model 26 electrobalance. DrY weights were corrected for losses due to preservation in formalin amounting to $40 \%$ on average. Tipid content of adult females and copepodid stage $V^{\prime}$ s were determined by repeated extraction in chloroform:inethanol $(2: 1, V: V)$. The difference in dry weight before and after extraction was the total weight of lipid in the copepod. Lipid loss due to preservation was estimated to be $47 \%$, based upon comparisons between fresh and preserved lipid contents measured in female calanus hyperboreus captured in the Greenland Sea. Conversions between dry weight and carbon were according to 
Cushing et al. (1958). Respiration was estimated using equations of Vidal and whitledge (1982).

The state of gonadal development in female calanoldes carinatus was noted and scored. The scale used in scoring was derived from those of Marshall and Orr (1972), Runge (1985), and Smith $(1990)$. Categories reflect the relative reproductive maturity of the females (Table 1 ).

Results

During the southwest monsoon of 1979, various stages of Calanoides carinatus were collected at 23 of 31 stations (Figure 1). The predominance of Calanoides carinatus in the tivo areas of upwelling (Smith 1982, 1984), the steepness of the gradients associated with upwelling features, and the speed of the somali Current make it difficult to depict the spatial pattern in secondary production. Therefore, the abundances of various stages are presented as a function of sea-surface temperature whose spatial distribution is shown in Figure 1 . The earliest copepodids, CI-CII, were collected in areas where sea-surface temperatures were between 18 and $20^{\circ} \mathrm{C}$ ( $94 \%$ of total numbers) with a maximum between 18 and $19^{\circ} \mathrm{C}$ (63\% of total numbers; Figure 2). Copepodid stage III also had its peak abundance between 18 and $19^{\circ} \mathrm{C}$, where $50 \%$ of total numbers were collected (Figure 2). Another 438 of total numbers of CIII were collected between 19 and $21^{\circ} \mathrm{C}$ (Figure 2). Copepodid stage IV showed a wider distribution, being relatively evenly spread between 18 and $23^{\circ} \mathrm{C}$ (Figure 2). Copepodid stage $V$ was bimodal, with $43 \%$ between 18 and $19^{\circ} \mathrm{C}$ and 298 between 
22 and $23^{\circ} \mathrm{C}$ (Figure 2). Adult females were most abundant in the temperature range in which CI's were dominant $\left(18-19^{\circ} \mathrm{C}\right)$, but 11 of the total numbers of females were collected where sea-surface temperatures were lowest $\left(16-18^{\circ} \mathrm{C} ;\right.$ Figure 2$)$.

Using the maximum specific dally production rates of juvenile Calanoides carinatus observed off southwest Africa (23) dry body weight per day; Verheye, 1989) and the daily rates of egg production observed of southwest Africa applied to females captured off Somalia $(60 \%$ dry body weight per day; Borchers and Hutchings, 1986), maximum secondary production was calculated for all stations where $c$. carimatus were captured. Highest potential secondary production occurred between 18 and $19^{\circ} \mathrm{C}$ (Figure 3). This reflects both the elevated concentrations of juvenile stages and reproductive females at these temperatures. Potential egg production accounted for an average of $84 \%$ of the calculated secondary production between 18 and $19^{\circ} \mathrm{C}$ (Figure 3 ). The distribution of nauplii confirms the fact reproduction was most intense where sea-surface temperatures were lowest (Figure 4).

Analysis of the state of gonadal development of adult females provides additional evidence that spawning by calanoides carinatus was taking place primarily nearshore. Thirty females from each of two stations nearshore and two stations offshore (Figure 1) were scored. Between 47 and $77 \%$ of the nearshore females had gonads in state 4 (see Table 1 for description of characteristics of various states), the state in which egg laying takes place. only 39 of nearshore females had gonads in state 1 , the state in which only the ovary is visible and oviducts contain no ooytes. In contrast 
with nearshore, between $57 t$ and $94 t$ of females collected offshore had gonads in state 1 and no offshore female had reached state 4. In summary, female $c$, carinatus with gonads fully developed and ready for egg laying were collected only nearshore. (The large numbers of copepod nauplii collected where sea surface temperatures were between 28 and $29^{\circ} \mathrm{C}$ are therefore not likely to be those of $\mathrm{C}$. carinatus.) When potential secondary production is averaged for nearshore stations (less than $9 \mathrm{~km}$ from the coast) and for of fhore stations (more than $250 \mathrm{~km}$ from the coast) where calanoides carinatus were collected, we find that potential secondary production is much higher nearshore (Figure 5). Most of the nearshore production is accounted for by egg production of females, while offshore egg production and growth of juveniles are of equal magnitude (Figure 5).

Another aspect of secondary production in this species is the large lipid reserve accumulated by copepodid stage $V$ (up to 71 of total dry body weight; Borchers and Hutchings, 1986). Lipid in females is found in two apparently separate lipid sacs, one in the forehead and one ventral to the gut a id oviducts (Figure 6). When females are without large numbers of eggs in the diverticula and oviducts, the lipid sacs are spherical or ellipsoid. As the eggs enlarge and fill the diverticula and oviducts, lipid sacs are deformed as shown in Figure 6. The presence or absence of lipid in females was correlated with gomadal development. All females from the two offshore stations, where gonad state was primarily 1, had observable lipid sacs. Of the adult females collected at the nearshore station where $77 \%$ were ready to lay eggs (state 4), only 
half had any visible lipid. of the females at the nearshore station where 47 were ready to lay eggs, 90 of females still had observable lipid. These data suggest that lipid reserves are used by females in the synthesis of eggs. Lipid content of females captured mearshore was 128 of dry body weight near 5 N and 4 of dry body weight near $10 \mathrm{~N}$ (Table 2): copepodid stage $\mathrm{V}$ captured offshore near $5^{\circ} \mathrm{N}$ contained an average of 41 lipid (Table 2 ).

\section{Discussion}

The life cycle of calanoides carimatus has been most fully described in areas of upwelling off the western coast of Africa, particularly off Ghana and the Ivory coast. The species is in surface layers during the upwelling season and spends the remainder of the year at mesopelagic depths (Mensah, 1974; Binet and suisse de st. Claire, 1975) where its respiration is fueled by stored lipids. The lipid that can be accumulated by copepodid stage V during feeding upon the upwelling assemblage of the Benguela Current can be considerable, up to 71 of dry body weight (Borchers and Hutchings, 1986). The evidence from the somali coast is consistent with patterns established for this species on the west coast of Africa. Secondary production, primarily reproduction, is highest in cool, recently upwelled waters nearshore. As juveniles move offshore in the somali current and the offshore-moving component of the Great whirl, their growth becomes a larger fraction of total potential secondary production of this species. The depths at which $C$. carimatus survives during the seasons lacking upiveliling off somalia are unknown, but it was not collected 
In the upper $200 \mathrm{~m}$ during the northeast monsoon of 1979 (Smith, 1982).

In another study we estimated ingestion from the summation of secondary production and respiration (Smith and Lane, 1988). Applying the same method to the calanoides carinatus collected at two nearshore stations (Figure 1), we find that daily ingestion could equal or exceed measured daily primary production at those stations. We can infer that during the upwelling season, growth of phytoplankton is closely coupled to the growth of the calanolides carinatus population. The life cycle of $c$. carinatus, wherever it is found, has distinctive characteristics that allow it to exploit a predictably intermittent food supply (Smith, 1982). These characteristics are rapid growth rate (Peterson and Painting, 1990), herbivorous feeding particularly on diatoms (Schnack, 1982), massive lipid storage by subadult stages (Borchers and Hutchings, 1986), and diapause at mesopelagic depths (Mensah, 1974; Binet and Suisse de sainte claire, 1975). These characteristics are very similar to those of large callanoid copepods inhabiting polar, subpolar and boreal environments.

\section{References}

BANSE, K. (1984) overview of the hydrography and associate. biological phenomena in the Arabian Sea, off Pakistan. IN: Marine Geology and Oceanography of Arabian Sea and coastal Pakistan, B.U." Haq and J.D. Milliman, eds., Van Nostrand Reinhold Company, New York, pp. 271-303. 
BINET, D. and E. SUISSE DE SAINTE CLAIRE (1975) Le copepode planktonique calanoldes cartinatus repartition et cycle blologique au large de la cote d'Ivoire, cahiers O.R.S.T.O.M., series Oceanographiquie, 13: 15-30.

BORCHERS, P. and L. HUTCHINGS (1986) Starvation tolerance, development time and egg production of Calanoides carinatus in the southern Bengilela Current, Journal of Plankton Research, 8: 85.5874.

BOUCHER, J., H. LAUREC, J.-F. SAMP.IN, and S. L. SMITH (1975) Etude de la nutrition, du regime et du rythme alimentaire du zooplancton dans les conditions naturelles, par la mesure des activites enzymatiques digestives, Tenth European Symposium on Marine Biology, 2: 85-110.

CUSHTNG, D. H., G. F. HUMPHREY, K. BANSE and T. LAEVASTU (1958) Report of the committee on terms and equivalents, Rapports et proces-verbaux les reunions, Conseil permanent international pour 1'exploration de la Mer, 144: 15-16.

MARSHALL, S. M. and A. P. ORR (1972) The Biology of a Marine Copepad, Springer Verlag, New York.

MENSAH, M. A. (1974) The reproduction and feeding of the marine copepod calanoides carinatus (Kroyer) in Ghanaian waters, Ghana Journal of sciemce, 14: 167-191. 
PETERSON, W. T. and $S$. J. PAINTING $(1990)$ Developmental rates of the copepods calamus australis and calanoldes carinatus in the laboratory, with discussion of methods used for calculation of development time, Journal of Plankton Research, 12: 28.3-293.

RUNGE, J. A. (1985) Relationship of egg production of Calanus pacificus to seasonal changes in phytoplankton availability in Puget sound, Washington, Limnology and oceanography, 30: 382-396.

SCHMACX, S. B. (1982) Feeding habits of Calanoides carinatus (Rroyer) in the upwelling area off northwest Africa, Rapports et proces-verbaux des reunions, comseil permanent international pour 1'exploration de la Mer, 18.0: 303-306.

SMITH, S.L. (1984) Biological indications of active upwelling in the northwestern Indian ocean in 1964 and 1979, and a comparison with Peru and northwest Africa, Deep-Sea Research, 31: 951-967.

SMITH, S.L. (1990) Egg production and feeding by copepods prior to the spring bloom of phytoplankton in fram strait, Greenland sea, Marine Biology, 106: 59-69.

SMITH, S.L. (1982) The nonthwestern Indain Ocean during the monsoons of 1979: distribution, abundance, and feeding of zooplankton, Deep-Sea Research, 29: 1331-1353. 
SMITH, S. L. and P. V. Z. LANE (1988) Grazing of the spring diatom bloom in the New York Bight by the calanoid copepods calanus Inmarchicus, Metridia lucens and Centropages typlcus, continental Shelf Research, 8: $485-509$.

SMITH, S. L. and P. V. Z. LANE (1981) Biological oceanography of the Somali Current Data Report, Informal Technical Report BNL 29098, Brookhaven National Laboratory, Upton, New York, 126 pp.

SWALLOW, J. C. (1984) Some aspects of the physical oceanography of the Indian Ocean, Deep-Sea Research, 31: 639-650.

VERHEYE, H. M. (1989), Distribution, dynamics and production of the copepod Calanoides carinatus (Kroyer, 1849) in the southern Benguela upwelling region. Ph.D. thesis, University of Capetown, Capetown, South Africa, 237 pp.

VIDAL, J. and T. E. WHITLEDGE (1982) Rates of metabolism of planktonic crustaceans as related to body weight and temperature of habitat, Journal of Plankton Research, 4 : 77-84.

WYRTKI, K. (1973) Physical oceanography of the Indian Ocean. IN: The Biology of the Indian ocean, B. Zeitzschel and S. Gerlach, eds. Springer-Verlag, New York, pp. 18-36. 
Acknowledgments

The research was supported by National science Foundation Grant OCE78-25454, and DOE Contract DE-ACO2-76CH00016 supported preparation of the manuscript. The Office of Naval Research funded my participation in the International symposium on the Oceanography of the Indian ocean. Analyses and data reduction were done by P.V.Z. Larie and E. Schwarting. 
Table 1. Callanolies carinatus. Description of reproductive state used for scoring female copepods collected of somalia (from smith, 1996)

state Morphological Description

1

2

small oucytes in ovary with sing e rows extending forward from ovary in diverticula; single row of small oocytes visiole in oviducts in lateral view

3

4

only ovary visible

oocytes larger with several rows extending forward in diverticula; medial walls of diverticula forced together; more than one row of eggs visible in oviducts in lateral view; eggs and ovary somewhat larger than in state 2

oocytes densely packed into diverticula; abutting medial walls of diverticula extend forward from ovary as dark line to anterior cephalothorax; large oocytes occupy much of cephalothorax; pouches of oocytes visible in oviducts in lateral view extending posteriorly to fifth thoracic segment

spert 
Table 2. Gonad development and lipid content of female falanoldes carinatus collected nearshore and of fhore

\begin{tabular}{|c|c|c|c|c|c|c|}
\hline \multirow{2}{*}{$\begin{array}{l}\text { Station } \\
\text { Nearshor }\end{array}$} & \multirow[t]{2}{*}{ Location } & \multicolumn{3}{|c|}{$\begin{array}{l}\text { Gonad } \\
\text { Development } \\
\text { (t) }\end{array}$} & \multirow[t]{2}{*}{$\begin{array}{l}\text { Lipid } \\
\text { Content } \\
(8)\end{array}$} & \multirow[t]{2}{*}{$\begin{array}{l}\text { Proportion of } \\
\text { Females } \\
\text { Lacking } \\
\text { Lipid (z) }\end{array}$} \\
\hline & & & & & & \\
\hline 13 & $\begin{array}{r}5^{\circ} 01^{\prime} \mathrm{N} \\
48^{\circ} 40^{\prime} \mathrm{E}\end{array}$ & $\begin{array}{l}\text { state } \\
\text { state } \\
\text { s-ate } \\
\text { state }\end{array}$ & $\begin{array}{l}1: \\
2: \\
3: \\
4:\end{array}$ & $\begin{array}{r}3 \\
23 \\
27 \\
47\end{array}$ & 12 & 10 \\
\hline 29 & $\begin{array}{l}10^{\circ} 13 \cdot \mathrm{N} \\
51^{\circ} 26^{\prime} \mathrm{E}\end{array}$ & $\begin{array}{l}\text { state } \\
\text { state } \\
\text { state } \\
\text { state }\end{array}$ & $\begin{array}{l}1: \\
2: \\
3: \\
4:\end{array}$ & $\begin{array}{r}3 \\
0 \\
20 \\
77\end{array}$ & 4 & 50 \\
\hline \multicolumn{7}{|c|}{ offshore } \\
\hline 19 & $\begin{array}{r}4^{\circ} 20^{\prime} \mathrm{N} \\
51^{\circ} 0^{\prime} \mathrm{E}\end{array}$ & $\begin{array}{l}\text { State } \\
\text { State } \\
\text { state } \\
\text { state }\end{array}$ & $\begin{array}{l}1: \\
2: \\
3: \\
4:\end{array}$ & $\begin{array}{r}94 \\
6 \\
0 \\
0\end{array}$ & 41 & 0 \\
\hline 20 & $\begin{array}{r}4^{\circ} 55^{\prime} \mathrm{N} \\
51^{\circ} 31^{\prime} \mathrm{E}\end{array}$ & $\begin{array}{l}\text { State } \\
\text { State } \\
\text { state } \\
\text { state }\end{array}$ & $\begin{array}{l}1: \\
2: \\
3: \\
4:\end{array}$ & $\begin{array}{r}57 \\
27 \\
16 \\
0\end{array}$ & $N D * *$ & 0 \\
\hline
\end{tabular}

*N.D. = Not determined. 
Figure Captions

Figure 1. The coast of somalia showing sea-surface temperature and positions of stations where calanoides carinatus were collected in 1979. Squares nearshore indicate stations in Table 2 and where ingestion has been estimated from secondary production and respiration. Squares offshore indicate stations used in Table 2 .

Figure 2. Abundance of juvenile (A) and adult (B) stages of Calanoides carinatus grouped according to sea-surface temperature at the station of collection.

Figure 3. Secondary production of Calanoides carinatus as a function of sea-surface temperature. Hatched portion of bar indicates estimate of egg production by females, remaınder of bar indicates estimate of somatic growth by subadult stages.

Figure 4. Abundance of copepod nauplii grouped according the sea-surface temperature at the point of collection.

Figure 5. Secondary production of Calanoides carinatus from stations less than $9 \mathrm{~km}$ from the coast (nearshore) and greater than $250 \mathrm{~km}$ from the coast (offshore). Hatched portion of bar indicates estimate of egg production by females, remainder of bar indicates estimate of somatic growth by subadult stages. 
Figure 6. Diagram of adult female Calanoides carinatus showing positions of lipid sacs (stippled areas) of females bearing eggs. The ovary (o), diverticula (d), oviducts (od) and gut (g) are also indicated. Females without eggs have lipid sacs that are spherical or ellipsoid in shape. 


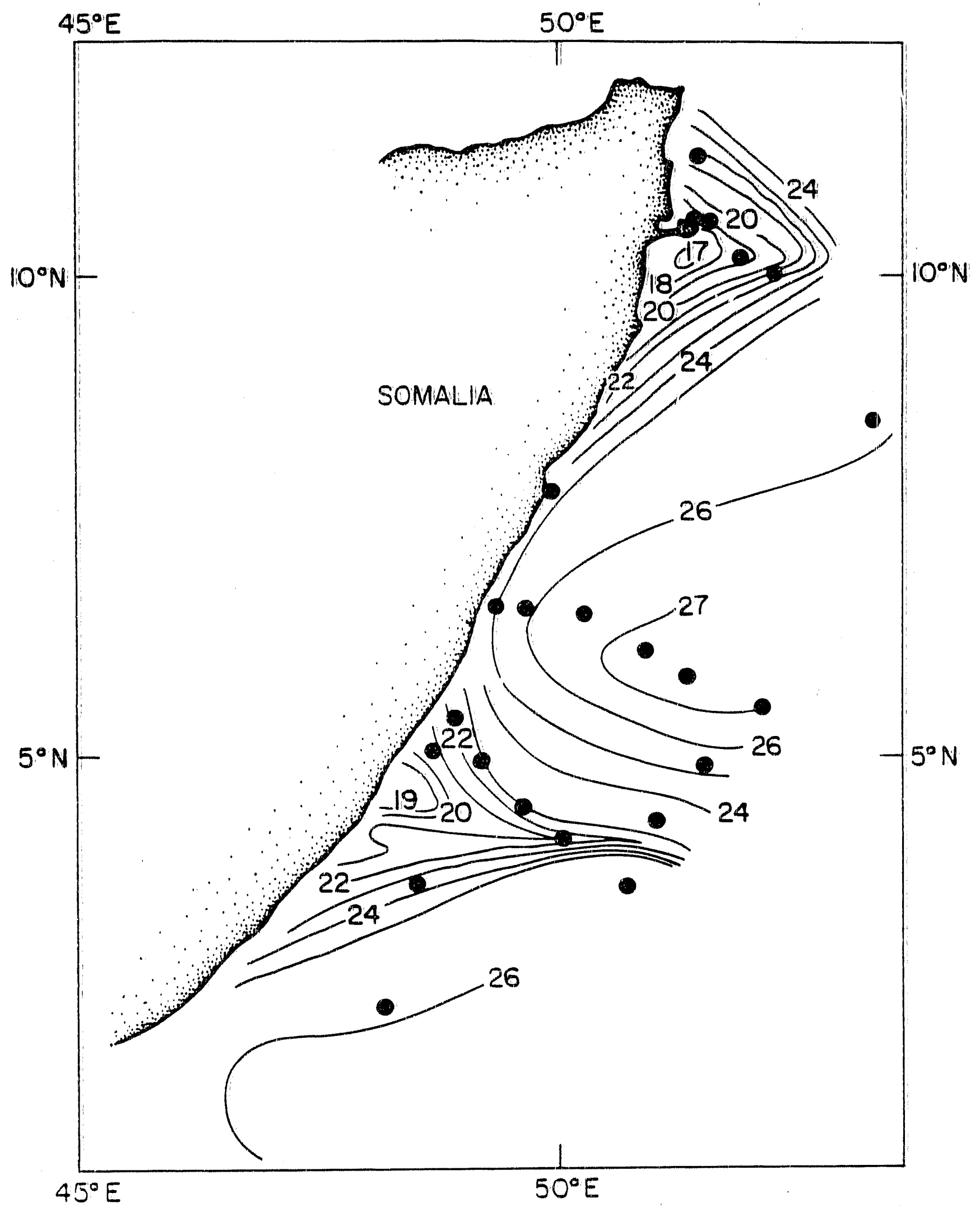


A
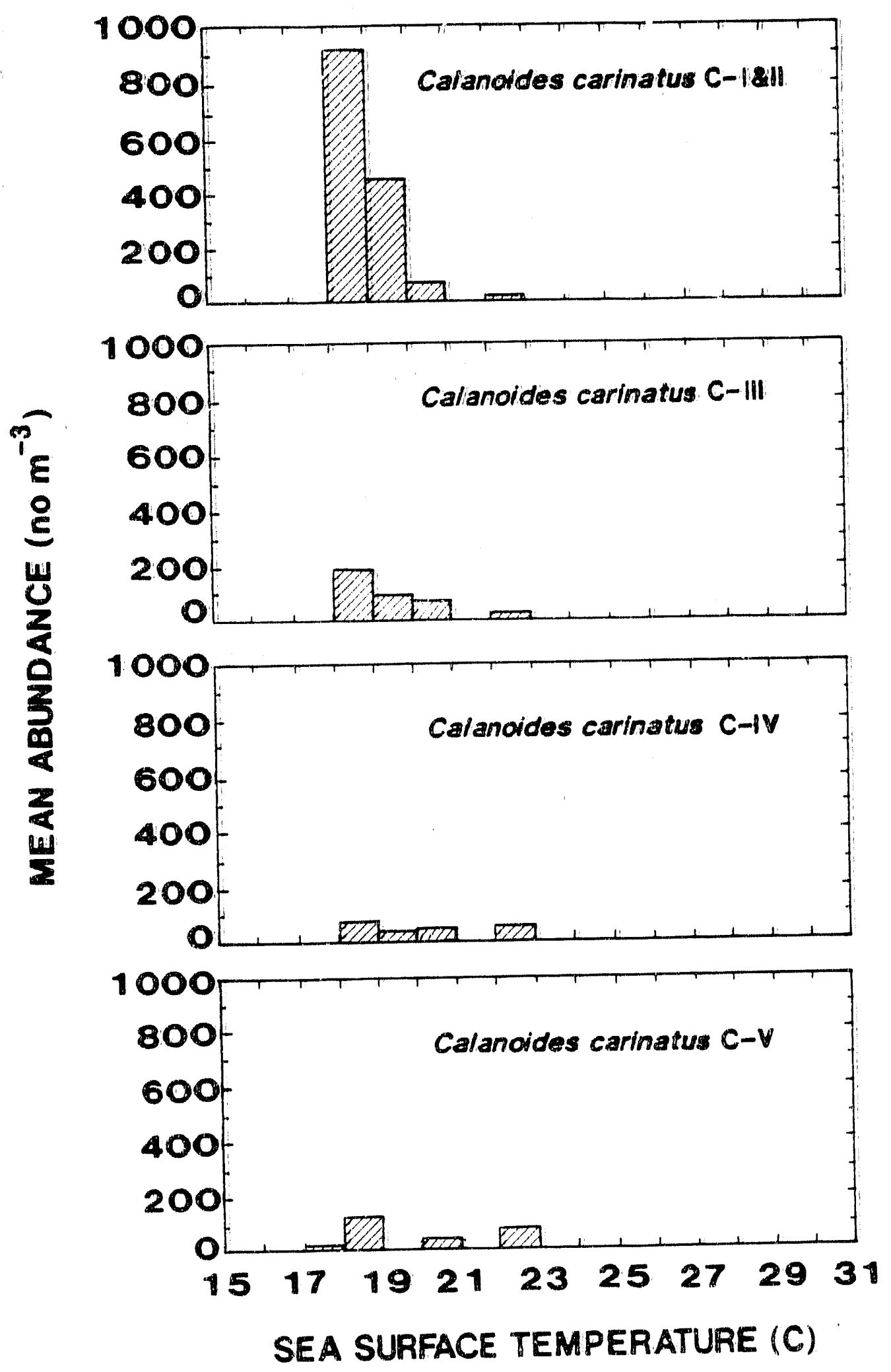


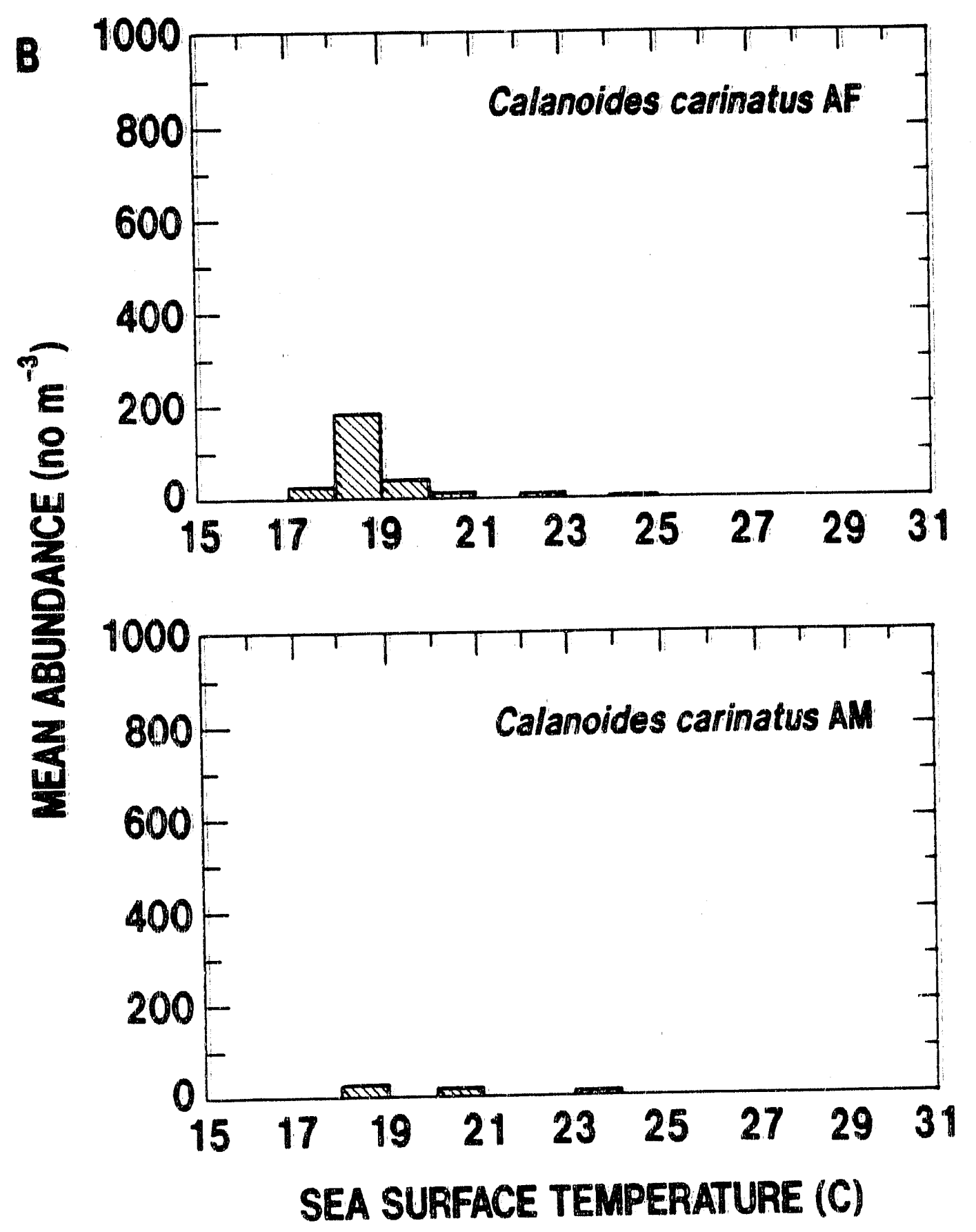




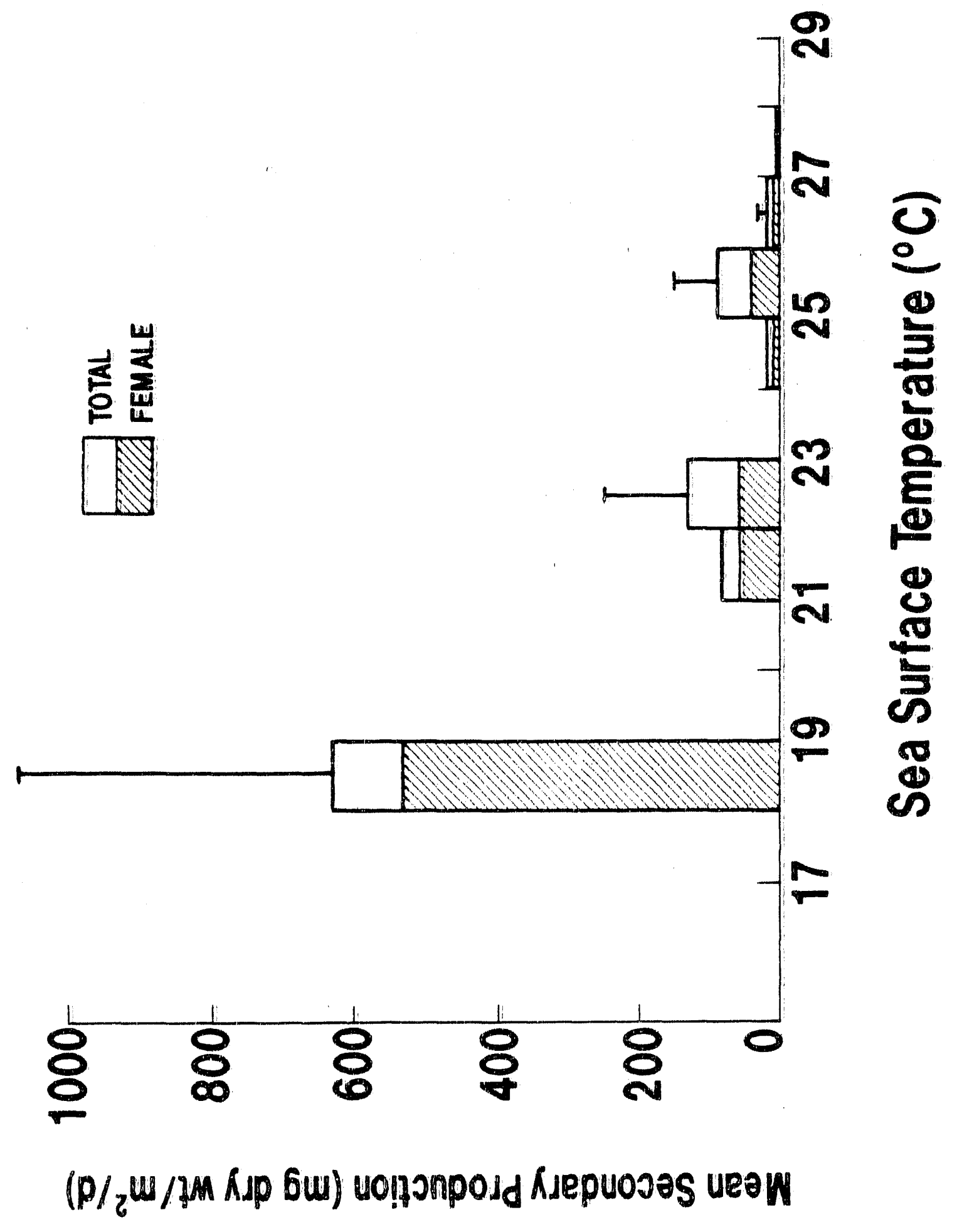




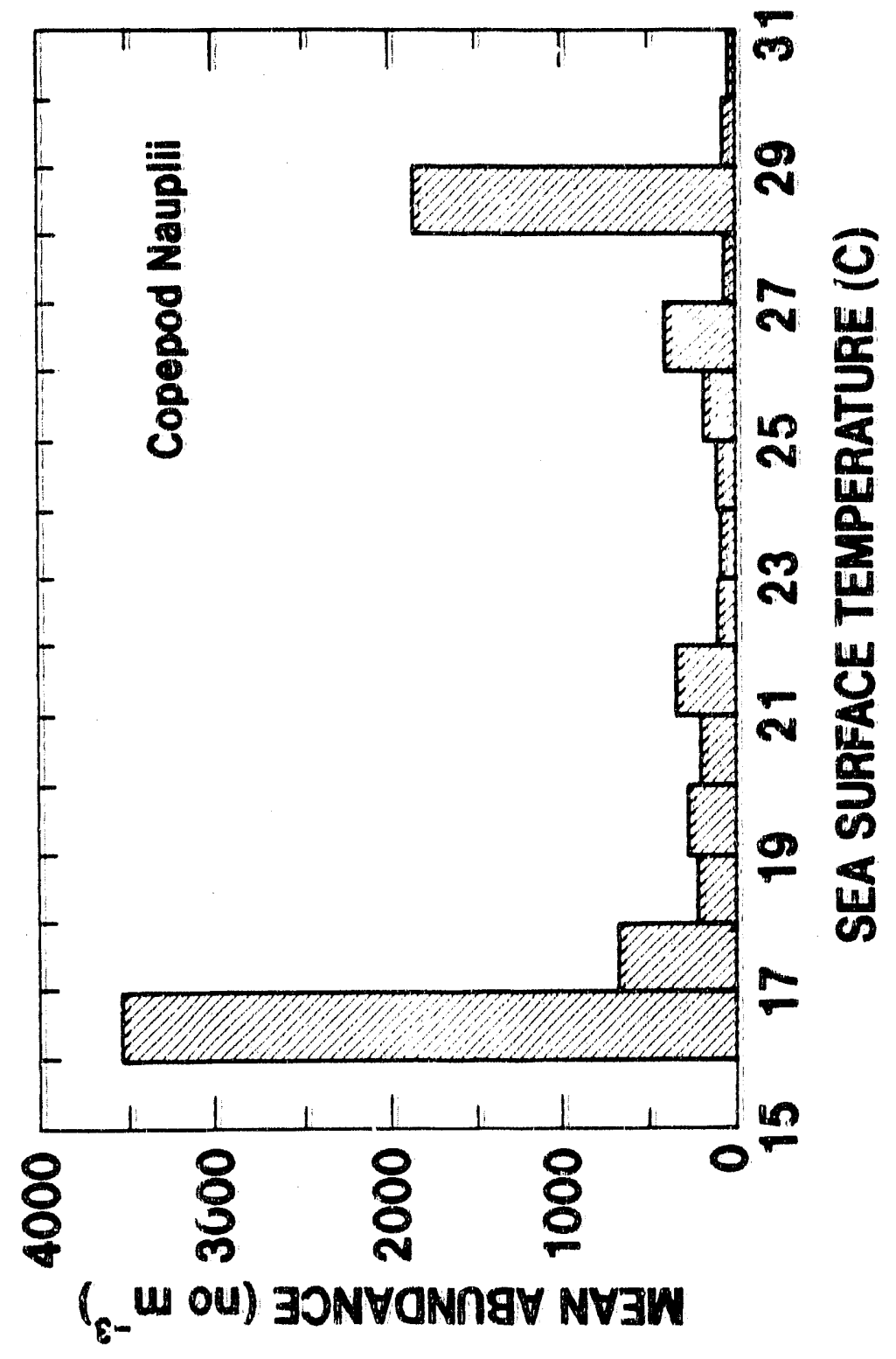




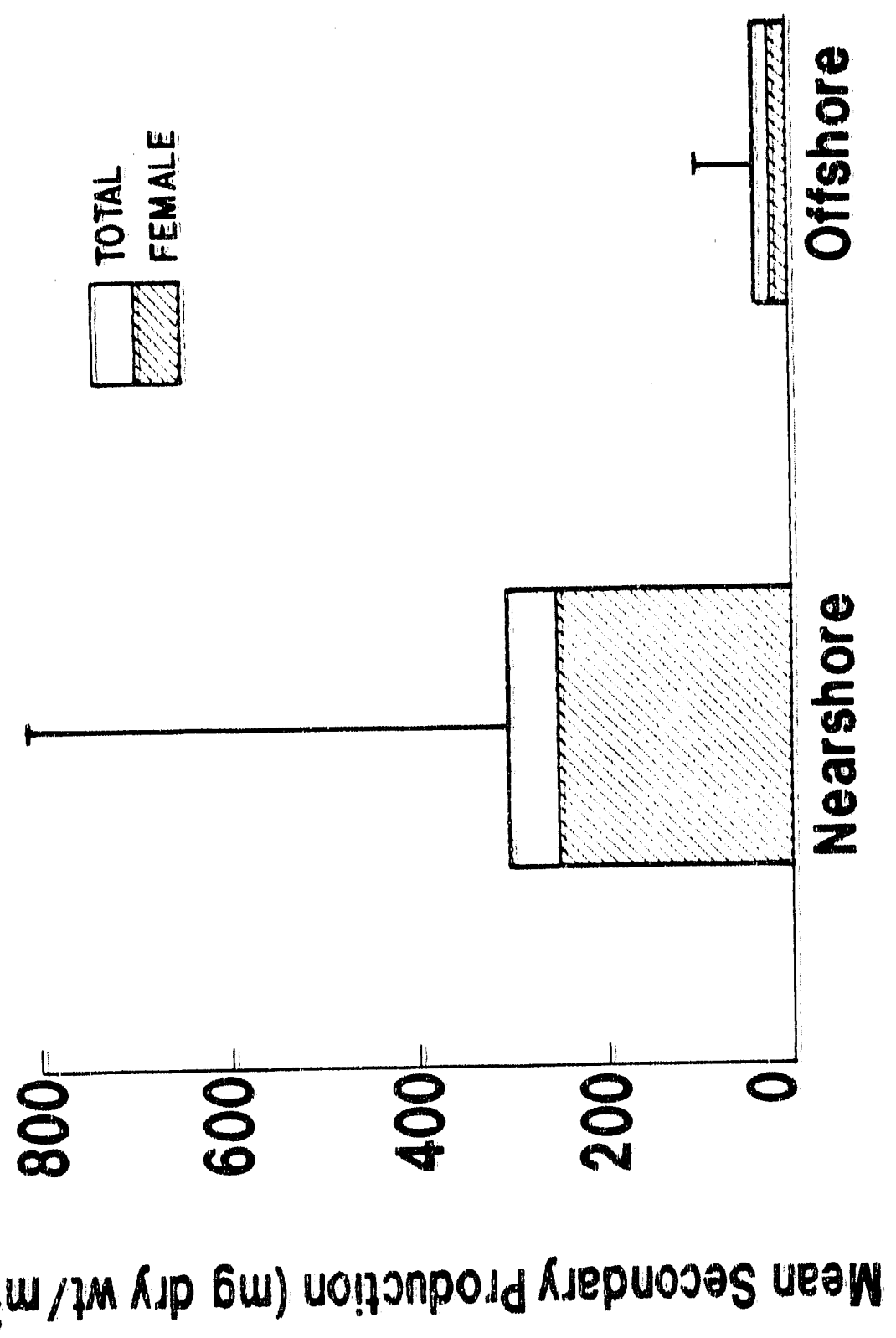




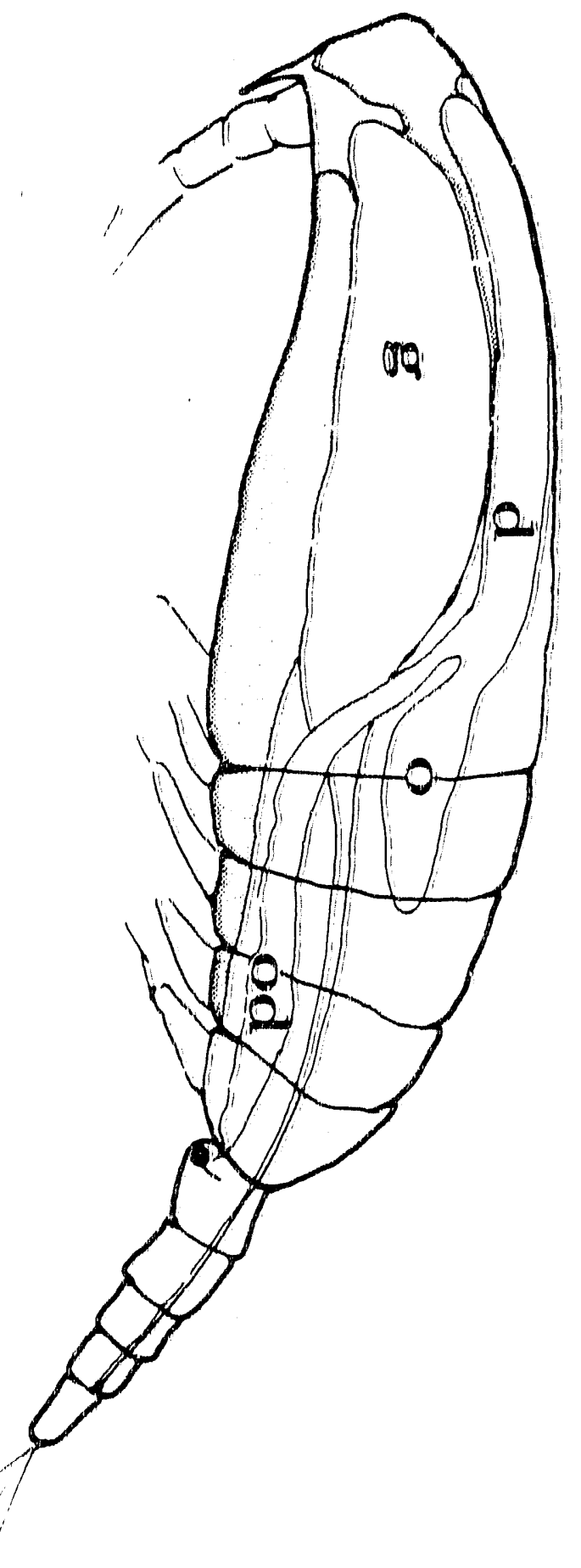




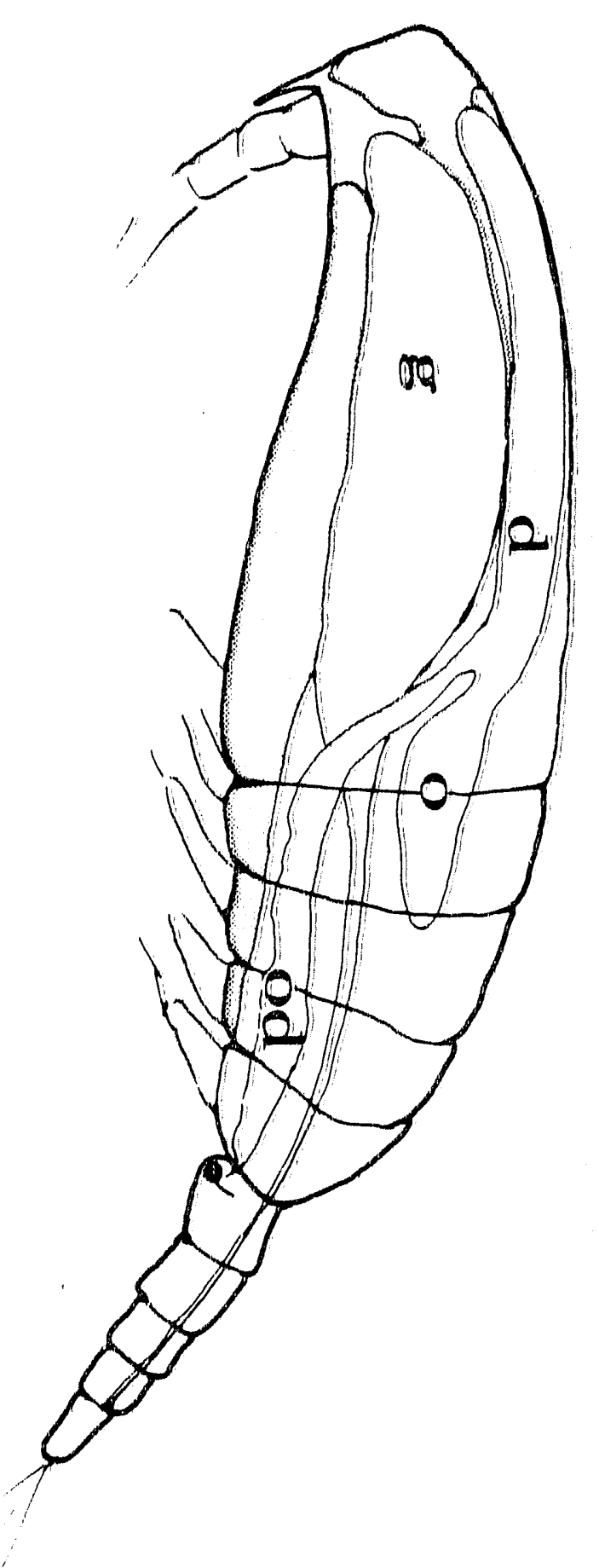




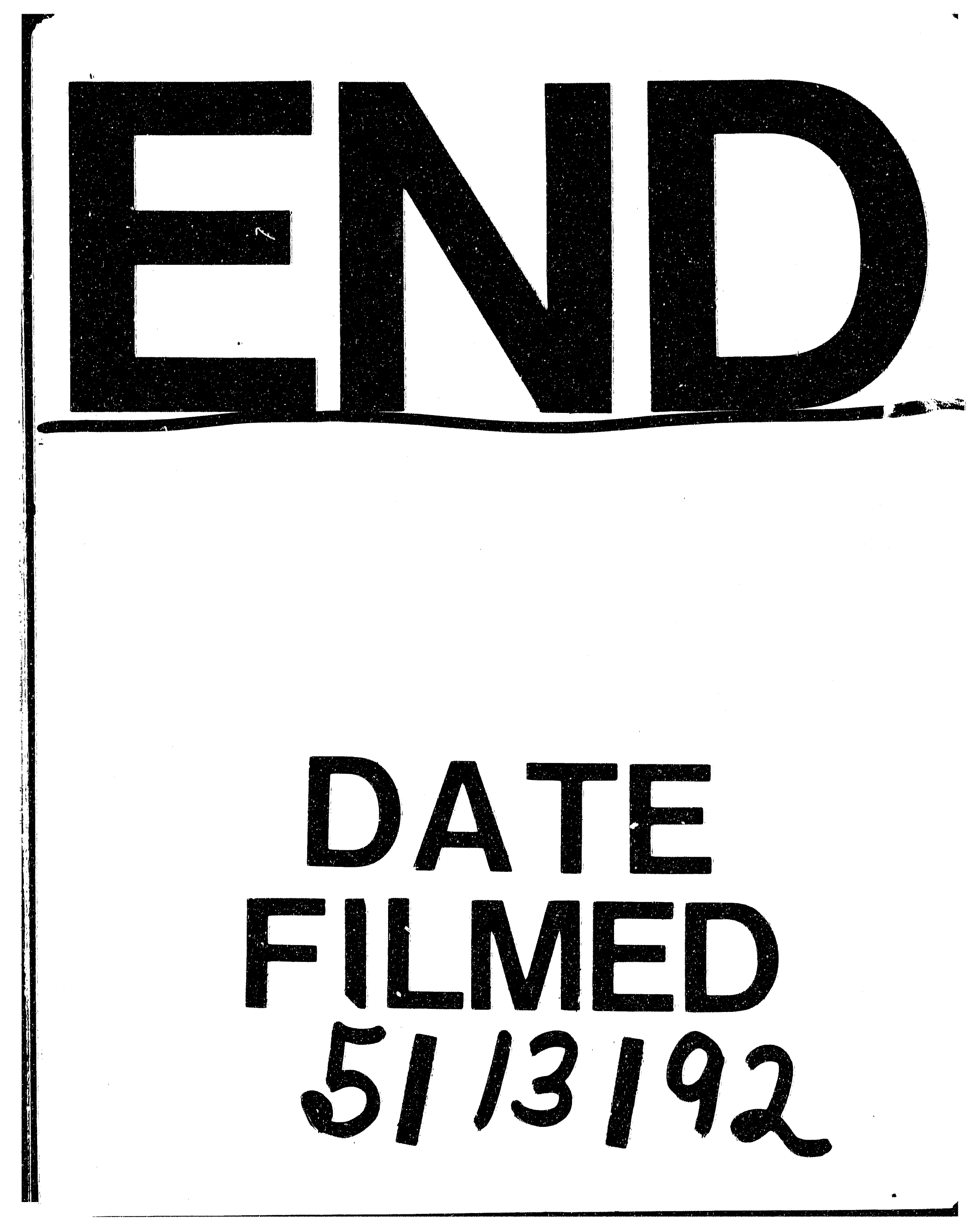

